\title{
A Comprehensive Survey On Student Perceptions Of Cyberbullying At A Major Metropolitan University
}

James P. Lawler, Pace University, USA

John C. Molluzzo, Pace University, USA

\begin{abstract}
Cyberbullying is a concern for any college or university. Digital harassment incidents are featured daily in the news. The authors of this study examine the perceptions of students on cyberbullying at a major metropolitan university. From the findings of a student survey, the authors learn of high levels of perceptions on incidents as an issue but low levels of perceptions on institutional methods of response and sensitivity at the university. This study will be beneficial as cyberbullying is considered an issue more frequent in high schools than in colleges and universities. ${ }^{I}$
\end{abstract}

Keywords: Cyberbullying; University; Sexting; Social Networking

\section{BACKGROUND}

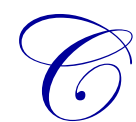

yberbullying is the abuse of choice of the "cyberimmersion generation" (Englander, 2009). Cyberbullying is "any behavior performed through digital or electronic media by [a college student or groups of college students] that repeatedly [over time] communicates aggressive or hostile messages intended to inflict discomfort or harm on [another student or other students]" (Tokunaga, 2010). Cyberbullying is about control (Roome, 2012) or dominance (Olthof, Goossens, Vermande, Aleva, \& Van Der Meulen, 2011) over another student. cyberbullying:

The behavior of cyber attackers, which is empowered by the Internet, is evident in the following forms of

- Cellular or digital imaging messages considered derogatory, harmful or mean to another student;

- $\quad$ Discussion board messages considered harmful or mean-spirited to another student;

- $\quad$ E-mails, instant messages, pictures, photographs or "sexting" of videos considered homophobic, racist or sexual if not humiliating and offensive to another student or students;

- $\quad$ "Flaming" or messaging on profiles on gaming or social networking sites considered offensive to another student or students; and

- Impersonating or messaging on gossip, personal polling or virtual reality sites or systems and "outing" or targeting other students if not stalking and threatening them (Reynolds, 2012).

This behavior may be initiated directly by an attacker or indirectly by an attacker engaging other students in attacking the victim (Wong-Lo, Bullock, \& Gable, 2009). The attacker may also cyberbully other students without the increased risk (Dempsey, Sulkowski, Nichols, \& Storch, 2009) that was evident when bullying was off-line. Cyberbullying is moreover "non-stop" (Mishna, Saini, \& Solomon, 2009), as it may continue beyond the location of the school. Impact is in increased through internalizing psychological problems manifested in cyberbullied students

\footnotetext{
${ }^{1}$ The authors of this paper are frequent researchers in cyberbullying. Previous research has focused on faculty perceptions of cyberbullying. The authors apply a consistent methodology to their research of cyberbullying in metropolitan universities.
} 
(Grene, 2003; Faryadi, 2011) - problems that may result in school shootings (Chapell et al., 2006) or suicides. Clearly cyberbullying is not the "fact of life" that bullying was without the Internet (Scott, 2012).

Estimates in the literature disclose that cyberbullying is experienced by $21 \%$ of high school students $21.8 \%$ of female and $19.5 \%$ of male students (Patchin \& Hinduja, 2012). High and middle school students experienced $17 \%$ of 1 or higher forms of incidents 2 to 3 times in the last 30 days, and experienced $14 \%$ of incidents in generic hurtful or mean-spirited messaging; and $16.8 \%$ of high and middle school students were attackers or perpetrators (Patchin \& Hinduja, 2012). Literature shows that cyberbullying may be experienced as frequently by college students: $22 \%$ of college students $-22 \%$ of female and $21.9 \%$ of male students - with $25 \%$ of incidents occurring on social networking sites (Indiana State University, 2011). Also 8.6\% of college students were perpetrators (MacDonald \& Roberts-Pittman, 2010), the bulk of whom were already middle, high or elementary school perpetrators or victims (Walker, Sockman, \& Koehn, 2011). Literature discloses even female students to be more involved in both perpetration and victimization (Snell \& Englander, 2010), though male students may be more involved in perpetration than female students (Chapell et al., 2004).Because the literature on cyberbullying is focused frequently on high school and middle school students, the impression may be that cyberbullying is limited to high and middle school students and not a problem for college students who are considered emerging adults (Zacchilli \& Valerio, 2011). Therefore, the authors of this study attempt to examine the perceptions of students on cyberbullying at a major metropolitan university in the United States.

\section{INTRODUCTION TO STUDY}

The authors examined cyberbullying in 2011 in a study of college students in courses in the Seidenberg School of Computer Science and Information Systems at Pace University in New York City (Molluzzo \& Lawler, 2011). A limitation of this study was a response of 121 students of a sample survey of 401 students in one school but not of students in the four other schools of the university. In this paper, the authors examine cyberbullying in an expanded survey of the perceptions of 7807 students in all 5 schools of the university to explore the extent of cyberbullying fully as a norm in the university.

This new study posits the following considerations on cyberbullying at Pace University:

- $\quad$ Extent to which students perceive cyberbullying as a generic issue in society and in a university;

- $\quad$ Extent to which students perceive cyberbullying as a specific issue in which they were victimized by other students in the university;

- $\quad$ Extent to which students perceive the culture of cyberbullying perpetration and pervasive technology in the university;

- $\quad$ Extent to which students perceive the culture of pro-action of preemption and resolution of cyberbullying by institutional and investigative officials in the university; and

- $\quad$ Extent to which students perceive and propose cyberbullying penalty and safety strategies of the university.

The paper focuses on the perceptions of the students as to the seriousness or non-seriousness of cyberbullying at the university and examines the extent of cyberbullying as perceived by students.

This paper is critical in learning the culture of cyberbullying in a major metropolitan university, as papers in the academic field focus more on cyberbullying prior to university (Zacchilli \& Valerio, 2011). Officials of a university need to be in a position to protectively but realistically respond to cyberbullying if students perceive perpetration problems, otherwise there may be liability potential (Willard, 2012) with the reality of victimization. Staff need to respond in reinforcement and safety solutions (Snakenborg, Van Acker, \& Gable, 2011) and software systems (Lieberman, Dinakar, \& Jones, 2011) shared with faculty and students.

\section{RESEARCH METHODOLOGY}

The study's research methodology consisted of a survey of the perceptions of all 7807 students at the College of Health Professions, Dyson College of Arts and Sciences, Lubin School of Business, School of Education, School of Law, and the Seidenberg School of Computer Science and Information Systems, of Pace University. 
The survey consisted of a cyberbullying definition (Tokunaga, 2010) and 47 items:

- 6 demographic questions;

- $\quad 7$ fundamental knowledge of cyberbullying questions;

- $\quad 9$ knowledge and perception of group or individual incidents and methods of cyberbullying perpetration questions;

- $\quad 14$ knowledge and perception of cyberbullying institutional response questions; and

- $\quad 11$ perception of seriousness or non-seriousness of cyberbullying as an issue at the university questions.

The survey was distributed in March to May 2012 through the e-mail system of the university, and the questions were furnished through the Qualtrics survey system. The responses returned to the authors were anonymous, and the students were assured of privacy of responses on the survey instrument. The authors reviewed the responses for statistical interpretation (McClave, Sincich, \& Mendenhall, 2007) in SPSS.

The survey instrument, which is available from the authors, was reviewed for feasibility and integrity by the University's Internal Review Board (IRB).

\section{ANALYSIS OF FINDINGS - PERSPECTIVES OF STUDENTS}

\section{Demographic Data}

There was a total of 355 student responses to the survey in which all the questions were answered. The respondents were distributed among the five schools of the university as follows: $53 \%$ Liberal Arts, $24 \%$ Business, $10 \%$ Computing, $8 \%$ Education, and 5\% Health Professions. 38\% of the respondents were Freshmen or Sophomores, $34 \%$ were Juniors or Seniors, and $28 \%$ were graduate students.

The university has an urban campus (64\% of the respondents) and a suburban campus $(37 \%$ of the respondents). $39 \%$ of the respondents live on campus, while $61 \%$ live off campus.

$73 \%$ of the respondents were female, $27 \%$ male. $64 \%$ of the respondents were 22 years of age or younger, $36 \%$ were 23 years of age or older.

\section{Student Awareness of Cyberbullying Issues}

The survey asked if the respondent was aware of cyberbullying as an activity on the Internet. $91 \%$ of the respondents either Strongly Agreed or Agreed. Using a Likert scale, the survey also probed for whether cyberbullying was a personal issue for the respondents. 52\% of the respondents either Strongly Agreed or Agreed. The survey asked if the respondent was aware of cyberbullying incidents at other universities. $84 \%$ either Strongly Agreed or Agreed. The survey also asked (using a 5-point Likert scale) if the respondent believed that cyberbullying was a serious issue at the university. 12\% of the respondents Agreed or Strongly Agreed, 27\% Strongly Disagreed or Disagreed, and 61\% Neither Agreed Nor Disagreed.

The University Core requires that all students take UNIV 101, which introduces them to college life, fosters good study habits, etc., and CIS 101, a required computer technology course. The survey asked if the respondents believed that cyberbullying should be discussed in these courses. $85 \%$ of respondents believed it should be discussed in UNIV 101, while 76\% believed that it should be discussed in CIS 101.

The survey asked if the respondents believed that professors at the university are knowledgeable on cyberbullying. 40\% Strongly Agreed or Agreed, $8 \%$ Strongly Disagreed or Disagreed, and 52\% neither Agreed nor Disagreed. The survey asked if the respondent's professors discussed cyberbullying in their courses, with $67 \%$ responding Yes. The survey also asked if cyberbullying was ever discussed in the respondent's fraternity or sorority, with $6 \%$ responding Yes.

$92 \%$ believe that cyberbullying is, pure and simple, wrong, and $78 \%$ of the respondents either Agree or Strongly 
Agree that cyberbullying is a violation of privacy. Only $41 \%$ of respondents feel knowledgeable on the laws of cyberbullying in the United States.

\section{Student Awareness of Cyberbullying Incidents}

The survey asked if the respondent was aware of cyberbullying incidents at the university. $12 \%(n=35)$ answered Yes. About one-third of those knowing of cyberbullying incidents reported just one incident. However, most others reported knowing several, and a few reported knowing five or more incidents. The survey also asked these respondents how many perpetrators were involved in the cyberbullying incidents of which they were aware. Most indicated that one or two perpetrators were involved, but a few people reported more than five and one person reported more than 20 perpetrators were involved.

Sometimes cyberbullying is not aimed at one person, but rather a group of people. Therefore, the survey asked those respondents who were aware of cyberbullying incidents how many victims were involved. Most responded that only one victim was involved, several responded that a few were victimized, and one person reported that about 20 people were victimized.

The survey asked also if the respondent was ever a perpetrator of cyberbullying. A surprising $12 \%(n=37)$ answered Yes. When asked if the respondent was ever a victim of cyberbullying, 9\% answered Yes. Most of these respondents were cyberbullied once by one person, but several of them responded more than one incident, and some were not sure. One unfortunate respondent answered that they had been cyberbullied for two entire semesters.

Of those who were cyberbullied, the survey asked how they were cyberbullied. The results are listed in Table 1. Note that the most used method was posting messages on Social Networking sites such as Facebook.

Table 1. What method was used to cyber-bully you in the university. Choose as many as appropriate

\begin{tabular}{lc}
\hline \multicolumn{1}{c}{ Answer } & \% Response \\
\hline Looking in to your cell phone & $13 \%$ \\
Looking in to your email & $17 \%$ \\
Sending you harassing emails & $29 \%$ \\
Sending you harassing pictures & $0 \%$ \\
Sending you pornographic images & $0 \%$ \\
Posting harassing messages on a social networking site & $71 \%$ \\
Posting harassing pictures on a social networking site & $17 \%$ \\
Preventing a friend from contacting others on a social networking site & $13 \%$ \\
Sexting & $13 \%$ \\
Other & $33 \%$ \\
\hline
\end{tabular}

The survey asked if the respondent was ever cyberbullied outside of the university. $28 \%(n=85)$ of the respondents replied Yes. Most of those who responded Yes were cyberbullied once or twice. However, fifteen respondents reported that they were cyberbullied many times. Table 2 lists the methods used to cyberbully these victims. Again, the most common vector was social networking sites.

Table 2. What method was used to cyber-bully you outside the university. Choose as many as appropriate.

\begin{tabular}{lc}
\hline \multicolumn{1}{c}{ Answer } & \% Response \\
\hline Looking in to your cell phone & $18 \%$ \\
Looking in to your email & $5 \%$ \\
Sending you harassing emails & $38 \%$ \\
Sending you harassing pictures & $11 \%$ \\
Sending you pornographic images & $11 \%$ \\
Posting harassing messages on a social networking site & $75 \%$ \\
Posting harassing pictures on a social networking site & $18 \%$ \\
preventing a friend from contacting others on a social networking site & $9 \%$ \\
Sexting & $17 \%$ \\
Other & $29 \%$ \\
\hline
\end{tabular}


Finally, the survey asked if the respondent was aware of cyberbullying of certain groups of people. The results of this questions are shown in Table 3. Note that Females (53\%) and Gays (53\%), and Lesbians (31\%) are the most cyberbullied groups.

Table 3. Are you aware of cyber-bullying of any of the following groups at Pace University? Choose as many as appropriate.

\begin{tabular}{lc}
\hline \multicolumn{1}{c}{ Answer } & \% Response \\
\hline Male students & $23 \%$ \\
Female students & $48 \%$ \\
Asian students & $17 \%$ \\
Gay students & $53 \%$ \\
Lesbian students & $31 \%$ \\
Physically disabled students & $27 \%$ \\
African-American students & $20 \%$ \\
Hispanic students & $20 \%$ \\
Muslim students & $17 \%$ \\
African students & $11 \%$ \\
Developmentally disabled & $22 \%$ \\
Other & $27 \%$ \\
\hline
\end{tabular}

\section{Student Response to Cyberbullying}

The survey asked whom a respondent would contact if they were a victim of cyberbullying. Table 4 lists the responses. Your best friend, your parents, and the counseling center all received more than a $50 \%$ response rate.

Table 4. If you were a victim of cyber-bullying, whom would you contact. Choose as many as appropriate

\begin{tabular}{lc}
\hline \multicolumn{1}{c}{ Answer } & \% Response \\
\hline The President of the University & $13 \%$ \\
The Dean of Students & $37 \%$ \\
The Dean of your school & $23 \%$ \\
The Chair of your department & $18 \%$ \\
The Counseling Center & $53 \%$ \\
The Security Department & $27 \%$ \\
Your local Police Department & $27 \%$ \\
Your fraternity or sorority & $13 \%$ \\
Your best friend & $68 \%$ \\
Your parents & $57 \%$ \\
No one & $9 \%$ \\
\hline
\end{tabular}

The survey also asked what should be the penalty for perpetrators of cyberbullying. Table 5 lists the responses. The most favored answer is a warning to the student (67\%), but $60 \%$ would also support suspension of the perpetrator.

Table 5. What should be the penalty for perpetrators of cyber-bullying? Choose as many as appropriate

\begin{tabular}{lc}
\hline \multicolumn{1}{c}{ Answer } & \% Response \\
\hline No penalty by the University & $3 \%$ \\
Warning sent to the student by the University & $67 \%$ \\
University informs police of the incident & $55 \%$ \\
Student is suspended by the University & $60 \%$ \\
University immediately expels the student & $17 \%$ \\
\hline
\end{tabular}

\section{Institutional Awareness}

Using a 5-point Likert scale, the survey asked two questions about institutional awareness of cyberbullying. Table 6 summarizes the results. Note that $40 \%$ of the respondents Strongly Agree or Agree that the university and the professors are knowledgeable of cyberbullying. 
Table 6. Who is knowledgeable on cyberbullying as an activity that is harmful to students?

\begin{tabular}{lcc}
\hline \multicolumn{1}{c}{ Answer } & The University Administration & The Professors at the University \\
\hline Strongly Disagree & $1 \%$ & $2 \%$ \\
Disagree & $6 \%$ & $6 \%$ \\
Neither Agree nor Disagree & $53 \%$ & $52 \%$ \\
Agree & $32 \%$ & $36 \%$ \\
Strongly Agree & $8 \%$ & $4 \%$ \\
\hline
\end{tabular}

The survey also asked if the respondent believed that the university as an institution is sensitive to the problems of cyberbullying. 24\% of the respondents Strongly Agreed or Agreed that the university is sensitive to cyberbullying, and 65\% Neither Agree nor Disagree.

The survey asked if the respondent was aware of the university's policies on cyberbullying. Only $17 \%$ Strongly Agreed or Agreed, while 60\% either Disagreed or Strongly Disagreed.

\section{Institutional Response}

The survey asked a series of questions on what the university should do to combat cyberbullying. Table 7 summarizes the results. The data show that there is an overwhelming feeling among the respondents that the university needs to do more to educate students, faculty and staff in the harmful effects of cyberbullying.

Table 7. The University Should ...

\begin{tabular}{lccccc}
\hline Answer & $\begin{array}{c}\text { Publicize More Its } \\
\text { Policy on } \\
\text { Cyberbullying. }\end{array}$ & $\begin{array}{c}\text { Publicize More the } \\
\text { Problems of } \\
\text { Cyberbullying as an } \\
\text { Activity Harmful to } \\
\text { Students. }\end{array}$ & $\begin{array}{c}\text { Sponsor Seminars } \\
\text { for Students on the } \\
\text { Problems of } \\
\text { Cyberbullying as an } \\
\text { Activity Harmful to } \\
\text { Students. }\end{array}$ & $\begin{array}{c}\text { Sponsor Sensitivity } \\
\text { Seminars for } \\
\text { Professors on the } \\
\text { Problems of } \\
\text { Cyberbullying as an } \\
\text { Activity Harmful to } \\
\text { Students. }\end{array}$ & $\begin{array}{c}\text { Sponsor Sensitivity } \\
\text { Seminars for Staf } \\
\text { on the Problems of } \\
\text { Cyberbullying as an } \\
\text { Activity Harmful to } \\
\text { Students. }\end{array}$ \\
\hline Yes & $84 \%$ & $89 \%$ & $80 \%$ & $76 \%$ & $75 \%$ \\
No & $16 \%$ & $11 \%$ & $20 \%$ & $24 \%$ & $25 \%$ \\
\hline
\end{tabular}

\section{DIFFERENCES AMONG DEMOGRAPHIC GROUPS}

The survey asked several questions on a 5-point Likert scale. Because our sample size was relatively small $(n=355)$, having five categories did not yield statistically valid results. It was felt that the Strongly Agree and Agree responses basically meant the same thing, and the other three responses meant the opposite - the respondent did not agree with the statement. Therefore, we combined these categories into two responses, which enabled a chi-squared test of independence on $2 \times 2$ cross-tabs. In addition to the Likert scale questions, there were many Yes/No questions in the survey. On these questions we performed chi-squared tests of independence on $2 \times 2$ cross-tabs.

\section{Gender}

Table 8 shows the significant differences between male and female respondents. In the Likert rows of the table, females were much more likely to agree than were males. The data in the Binary rows of the table show there is a very strong gender difference on these questions. In all cases, females were more likely to respond Yes. 
Table 8. Gender Differences

\begin{tabular}{lcc}
\hline \multicolumn{1}{c}{ Question } & $\boldsymbol{p}<\mathbf{. 0 0 1}$ & $\boldsymbol{p}<\mathbf{0 1}$ \\
\hline Likert: & & 0.004 \\
\hline $\begin{array}{l}\text { Cyberbullying is a serious issue for you. } \\
\text { Professors at the university are knowledgeable on cyberbullying as an activity that } \\
\text { is harmful to students. }\end{array}$ & 0.002 \\
$\begin{array}{l}\text { Cyberbullying is a violation of privacy, regardless of the intent of the perpetrator. } \\
\text { Cyberbullying, pure and simple, is wrong. }\end{array}$ & 0.000 \\
\hline Binary: & 0.000 & 0.023 \\
\hline $\begin{array}{l}\text { Should cyberbullying be discussed in UNIV 101? } \\
\text { Should cyberbullying be discussed in CIS 101? }\end{array}$ & 0.000 \\
$\begin{array}{l}\text { Should the university publicize more its policy on cyberbullying? } \\
\text { Should the university publicize cyberbullying as an activity harmful to students? }\end{array}$ & 0.000 \\
$\begin{array}{l}\text { Should the university sponsor seminars for students on the problems of } \\
\text { cyberbullying as an activity harmful to students? }\end{array}$ & \\
$\begin{array}{l}\text { Should the university sponsor sensitivity seminars for professors on the problems } \\
\text { of cyberbullying as an activity harmful to students? }\end{array}$ & 0.000 \\
\hline
\end{tabular}

\section{Age}

Table 9 shows the statistically significant differences between students 22 years of age and under, and students 23 years of age and older. In the Likert rows, with only one exception, younger students tended to agree more than the older students. The exception was on the question - the university is sensitive to the problems of cyberbullying. This could be the result of undergraduate students feeling more aware of cyberbullying. In all the Binary rows of the table, the younger students were more likely to answer Yes.

Table 9. Age Differences

\begin{tabular}{|c|c|c|c|}
\hline Question & $p<.001$ & $p<.01$ & $p<.05$ \\
\hline \multicolumn{4}{|l|}{ Likert: } \\
\hline Are you aware of cyberbullying as an activity on the Internet? & & 0.002 & \\
\hline Are you aware of cyberbullying activities at other schools? & & & 0.011 \\
\hline The university, as an institution, is sensitive to the problems of cyberbullying. & & 0.003 & \\
\hline Cyberbullying is a violation of privacy, regardless of the intent of the perpetrator. & & & 0.018 \\
\hline Cyberbullying, pure and simple, is wrong. & & & 0.017 \\
\hline \multicolumn{4}{|l|}{ Binary: } \\
\hline $\begin{array}{l}\text { Have professors in your courses at the university discussed incidents or issues of } \\
\text { cyerbullying? }\end{array}$ & & 0.006 & \\
\hline Are you aware of incidents of cyberbullying at the university? & & 0.004 & \\
\hline Have you ever consciously or unconsciously been a perpetrator of cyberbullying? & 0.001 & & \\
\hline Have you ever been a victim of cyberbullying at the university? & & 0.003 & \\
\hline
\end{tabular}

\section{Campus}

Campus also was a differentiating factor among respondents. The two campuses of the university are quite different - one is a highly urban campus situated in a major financial center. The other campus is suburban, several miles from the nearest city. Table 10 shows the statistically significant differences between the two campuses. In Questions 8, 66, and 67 the suburban students were more likely to agree with the statement. For reasons that are not clear, it appears that the suburban students are a bit more aware of cyberbullying issues. Question 65 was the only one in which the urban students were more likely to agree. 
Table 10. Urban Campus vs. Suburban Campus

\begin{tabular}{lcc}
\hline \multicolumn{1}{c}{ Question } & $\boldsymbol{p}<. \mathbf{0 1}$ & $\boldsymbol{p}<\mathbf{. 0 5}$ \\
\hline Likert: & & 0.049 \\
\hline Are you aware of cyberbullying as an activity on the Internet? & 0.037 \\
You are knowledgeable of the laws of cyberbullying in the United States, & 0.028 \\
Cyberbullying is a violation of privacy, regardless of the intent of the perpetrator. & 0.008 & \\
Cyberbullying, pure and simple, is wrong. & \\
\hline Binary & & 0.051 \\
\hline Should cyberbullying be discussed in CIS 101? & \\
\hline
\end{tabular}

The only Binary question row of Table 10 shows a barely significant difference $(p=0.051)$ between urban students as opposed to suburban students on the question of whether cyberbullying should be taught in UNIV 101, with the suburban students slightly more likely to respond Yes.

\section{School}

The university consists of a large liberal arts school and four professional schools. Table 11 shows there was a significant difference on question Q9, with the liberal arts students considering it more of an issue. Also in question Q67, there was a significant difference between liberal arts and professional school students considering whether cyberbullying is, pure and simple, wrong.

Table 11. Liberal Arts vs. Professional Schools

\begin{tabular}{|c|c|c|c|}
\hline Question & $p<.001$ & $p<.01$ & $p<.05$ \\
\hline Likert: & & & \\
\hline $\begin{array}{l}\text { Cyberbullying is a serious issue for you. } \\
\text { Cyberbullying, pure and simple, is wrong. }\end{array}$ & & 0.002 & 0.022 \\
\hline Binary & & & \\
\hline $\begin{array}{l}\text { Should cyberbullying be discussed in UNIV } 101 ? \\
\text { Have you ever been a victim of cyberbullying at the university? }\end{array}$ & & 0.008 & 0.020 \\
\hline
\end{tabular}

The Binary section of Table 11 shows that professional school students were more likely to believe that cyberbullying should be discussed in UNIV 101. However, liberal arts students were more likely to have been a victim of cyberbullying.

\section{On-Campus vs. Off-Campus}

At the university, approximately $37 \%$ of students live on campus. The rest are commuter students. Table 12 shows the only Likert question, Q64, in which there was a significant difference between students living on campus and those living off campus, with the on-campus students less likely to agree that the university is sensitive to cyberbullying issues. In the Binary rows of the table, in all cases, except for question 49, students living on campus were more likely to respond Yes.

Table 12. Living On-Campus vs. Living Off-Campus

\begin{tabular}{lc}
\multicolumn{1}{c}{ Question } & $\boldsymbol{p}<\mathbf{0 0 1}$ \\
\hline \multicolumn{1}{c}{ Table 12. Living On-Campus vs. Living Off-Campus } & $\boldsymbol{p}<\mathbf{0 5}$ \\
\hline Likert: & 0.001 \\
\hline The university, as an institution, is sensitive to the problems of cyberbullying. & \\
\hline Binary: & 0.040 \\
\hline $\begin{array}{l}\text { Have you discussed issues of cyberbullying in your fraternity or sorority at the } \\
\text { university? }\end{array}$ & 0.020 \\
Should cyberbullying be discussed in CIS 101? & 0.013 \\
Are you aware of incidents of cyberbullying at the university? & 0.000 \\
Have you ever consciously or unconsciously been a perpetrator of cyberbullying? & \\
Have you ever been a victim of cyberbullying at the university? & 0.028 \\
\hline
\end{tabular}




\section{Undergraduate vs. Graduate}

Table 13 summarizes the significant differences between graduate students and undergraduate students. On question Q64 there was a significant difference between undergraduate and graduate students, with the undergraduate students more likely to believe that the university is not sensitive to cyberbullying. In all the Binary questions, except for question 48, undergraduate students were more likely to answer Yes. It is interesting to note that graduate students were more likely to want cyberbullying discussed in UNIV 101. Although graduate students do not take this course, many of the university's graduate students received their undergraduate degree from the university. Therefore, their response might be indicative of their undergraduate education at the university.

Table 13. Undergraduate vs. Graduate

\begin{tabular}{|c|c|c|}
\hline Question & $p<.01$ & $p<.05$ \\
\hline \multicolumn{3}{|l|}{ Likert: } \\
\hline The university, as an institution, is sensitive to the problems of cyberbullying. & 0.006 & \\
\hline \multicolumn{3}{|l|}{ Binary: } \\
\hline Should cyberbullying be discussed in UNIV $101 ?$ & & 0.017 \\
\hline $\begin{array}{l}\text { Have professors in your courses at the university discussed incidents or issues of } \\
\text { cyerbullying? }\end{array}$ & 0.002 & \\
\hline Have you ever consciously or unconsciously been a perpetrator of cyberbullying? & 0.004 & \\
\hline Have you ever been a victim of cyberbullying at the university? & & 0.012 \\
\hline
\end{tabular}

\section{IMPLICATIONS OF STUDY}

The study shows that cyberbullying is a serious issue for university students. A vast majority of the respondents also believe that cyberbullying is wrong and a violation of one's privacy. This belief is confirmed by Table 5, which shows a majority of students want perpetrators of cyberbullying suspended from the university.

The study shows that most students (91\%) are aware of cyberbullying on the Internet, while $52 \%$ believe that cyberbullying is a serious problem for themselves. These percentages show that cyberbullying is a serious concern among college students.

The study also revealed some information that might be useful to a university's administration. Only $44 \%$ of students believe that the university or their professors (see Table 6) are knowledgeable of cyberbullying as an activity harmful to students. Finally, as shown in Table 7, a majority of students believe the university should do much more to educate the university community on the problems of cyberbullying.

\section{CONCLUSION}

This study confirmed that cyberbullying is a concern for the students of the university. Knowledge of the students of the proactive processes for safety steps with the institutional problems of perpetration and victimization were disclosed in the study. The study also showed that the university needs to be more proactive in educating the university community in the problems of cyberbullying and that these problems are evident in the setting of a university and are not limited to high school settings. A forthcoming paper by the authors will compare the results of this study with that of a previously published study (Molluzzo, Lawler \& Manneh, 2013) of the perceptions of cyberbullying by professors at the university.

\section{ACKNOWLEDGEMENTS}

The authors acknowledge the cooperation of the Provost, the Internal Review Board (IRB) at Pace University, and especially the Dean for Students, Dr. Marijo Russell-O'Grady, in the formulation of the program for and dissemination of the student survey at the university. 


\section{AUTHOR INFORMATION}

Dr. James P. Lawler is Professor of Disability Studies, Information Technology and Service-Learning at the Seidenberg School of Computer Science and Information Systems of Pace University and is a researcher in disability empowerment and self-advocacy technologies. E-mail: jlawler@pace.edu (Corresponding Author)

Dr. John C. Molluzzo is Professor of Information Technology at the Seidenberg School of Computer Science and Information Systems at Pace University. He has held positions at the City University of New York and St. John's University. He is the author of nine books in mathematics and computing, and has authored over 40 articles in mathematics, computer science, and information technology. Currently he is engaged in several research projects involving the effects of technology on society. E-MAIL: jmolluzzo@pace.edu

\section{REFERENCES}

Chapell, M., et al. (2004). Bullying in college by students and teachers. Adolescence, 39, 53-64.

Chapell, M., Hasselman, S.L., Kitchin, T., Lomon, S.N., Maclver, K.W., \& Sarullo, P. (2006). Bullying in elementary school, high school and college. Adolescence, 41, 633-648.

Dempsey, A.G., Sulkowski, M.L., Nichols, R., \& Storch, E.A. (2009). Differences between peer victimization in cyber and physical settings and associated psychosocial adjustment in early adolescence. Psychology in the Schools, 46, 962-972.

Englander, E., Mills, E., \& McCoy, M. (2009). Cyberbullying and information exposure: User-generated content in post-secondary education [Special edition]. International Journal of Contemporary Sociology, 46(2), 213230.

Faryadi, Q. (2011). Cyberbullying and academic performance. International Journal of Computational Engineering Research, 1(1), 23-30.

Grene, M.B. (2003). Counseling and climate change as treatment modalities for bullying in school. International Journal for the Advancement of Counseling, 25(4), 293-302.

Lieberman, H., Dinakar, K., \& Jones, B. (2011). Let's gang up on cyberbullying: The novel design of social network software can help prevent and manage the growing problem of cyberbullying. Computer, 9(44), 93-96.

MacDonald, C.D., \& Roberts-Pittman, B. (2010). Cyberbullying among college students: Prevalence and demographic differences. Procedia: Social and Behavioral Sciences, 9, 2003-2009.

McClave, J., Sincich T., \& Mendenhall, W. (2007). Statistics, $11^{\text {th }}$ Edition. Upper Saddle River, NJ: Pearson Prentice-Hall.

Mishna, F., Saini, M., \& Solomon, S. (2009). On-going and on-line: Children and youths' perceptions of cyberbullying. Children and Youth Services Review, 31, 1222-1228.

Molluzzo, J.C., \& Lawler, J.P. (2011). A study of the perceptions of college students on cyberbullying. Proceedings of the Information Systems Educators Conference (ISECON), 28(1633), 1-25.

Molluzzo, J.C., Lawler, J.P., \& Manneh, J. (2013). A comprehensive survey on cyberbullying perceptions at a major metropolitan university-Faculty perspectives. Information Systems Education Journal, 11(3), May, 15-34.

Olthof, T., Goossens, F.A., Vermande, M.M., Aleva, E.A., \& Van Der Meulen, M. (2011). Bullying as strategic behavior: Relations with desired and acquired dominance in the peer group. Journal of School Psychology, 49(3), 339-359.

Reynolds, G.W. (2012). Ethics in information technology (5 $5^{\text {th }}$ ed.). Boston, MA: Cengage Learning.

Roome, D. (2012). Cyberbullying is never alright: Dealing with the pain of cyberabuse. Lexington, KY: CreateSpace.

Sicking, J. (2011, October 20). Bullying still occurs in college, professors find. Indiana State University (ISU) Newsroom. Retrieved from http://www.indstate.edu/news/news.php?newsid=2904

Scott, A.O. (2012, March 30). Behind every harassed child? A whole lot of clueless adults. The New York Times, p. C10.

Snakenborg, J., Van Acker, R., \& Gable, R.A. (2011). Cyberbullying: Prevention and intervention to protect our children and youth. Preventing School Failure, 55(2), 88-95.

Snell, P.A., \& Englander, E.K. (2010). Cyberbullying victimization and behaviors among girls: Applying research findings in the field. Journal of Social Sciences, 6(4), 510-514. 
Tokunaga, R.S. (2010). Following you home from school: A critical review and synthesis of research in cyberbullying victimization. Computers in Human Behavior, 26, 277-287.

Walker, C.M., Sockman, B.R., \& Koehn, S. (2011). An exploratory study of cyberbullying with undergraduate university students. TechTrends, 55(2), 31-38.

Willard, N. (2012). Cyberbullying and the law. In J.W. Patchin, \& S. Hinduja (Eds.), Cyberbullying Prevention and Response: Expert Perspectives. Boca Raton, Florida: Taylor \& Francis Group, 47.

Wong-Lo, M., Bullock, L.M., \& Gable, R.A. (2009). Cyberbullying: Facing digital aggression. Proceedings of the Conference of the Teacher Education Division of the Council of Exceptional Children, Charlotte, North Carolina.

Zacchilli T. L., \& Valerio C. Y. (2011). The knowledge and prevalence of cyberbullying in a college sample. Journal of Scientific Psychology, 11-23, Retrieved from http://www.psyencelab.com/images/The_Knowledge_and_Prevalence_of_Cyberbullying_in_a_College_Sa mple.pdf 


\section{NOTES}

